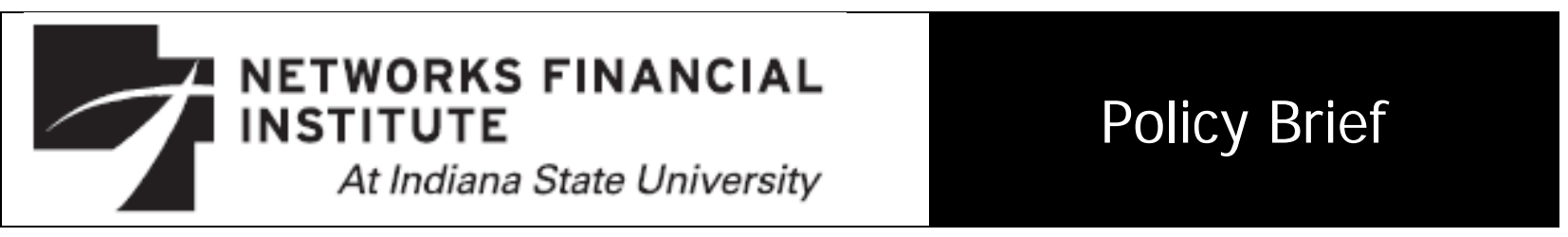

2009-PB-07

November 2009

\title{
Glass-Steagall in Our Future: How Straight, How Narrow Martin Mayer
}

Abstract: A dozen years ago, Randall Kroszner, soon to be one of George W. Bush's economic advisors and a Governor of the Federal Reserve, could comment in a Levy Institute seminar, without fear of contradiction, that there was no evidence to back the "public interest rationale" for the separation of commercial and investment banking. Except for deposit insurance (and even here, there were mutterings about moral hazard), the limits imposed on banking by the Glass-Steagall Act of 1933 were roundly condemned through the entire cadre of academic and corporate economists, as the old law was unceremoniously junked 66 years later. A few of us did worry about the loss of information that could result as the veil of bank secrecy was extended over additional transactions, but we were not really respectable. Today, we few stand on the high ground of observed recent experience and watch the survivors of the still-acclaimed wave of financial innovation struggle defensively, if not repentantly, up the slopes of what Alan Greenspan called "shocked disbelief." Ten years after its repeal, Glass-Steagall has a constituency again.

About the Author: Martin Mayer, Brookings Institution Guest Scholar since 1993, is the author of 35 books. His first financial books date back to the 1950s. While for several years he worked mostly in the field of education, he returned to financial markets in 1975 with The Bankers. His book The Builders led to his service as a commissioner on Ronald Reagan's National Commission on Housing. The Fate of the Dollar, published in 1979, detailed the decline of the currency in the 1960s and '70s, and The Money Bazaars in 1983 predicted the dominance of the capital markets over the credit markets. Markets: Who Plays, Who Risks, Who Gains, Who Loses told the story of the 1987 crash and the rise of Chicago and Tokyo, while The Greatest Ever Bank Robbery in 1990 told the savings and loan story. Stealing the Market (1991) worried about front-running, and Nightmare on Wall Street dealt with the Salomon Brothers' attempt to corner the market in an auction of two-year Treasuries. In 1997, The Bankers: The Next Generation centered on the oncoming derivatives disaster and was followed by The Fed, published in 2002. Through most of those years he was also a professional music and opera critic and historian.

Keywords: Glass-Steagall Act, Gramm-Leach Bliley Act, Financial Crisis, Financial Regulatory Reform

EL Classification: G2, G01, G18

The views expressed are those of the individual author and do not necessarily reflect official positions of Networks Financial Institute. Please address questions regarding content to Martin Mayer at mmayer2a1@aim.com. Any errors or omissions are the responsibility of the author. NFI working papers and other publications are available on NFI's website (www.networksfinancialinstitute.org). Click "Thought Leadership" and then "Publications/Papers." 


\section{Glass-Steagall in Our Future: How Straight, How Narrow}

Martin Mayer

A dozen years ago, Randall Kroszner, soon to be one of George W. Bush’s economic advisors and a Governor of the Federal Reserve (Fed), could comment in a Levy Institute seminar, without fear of contradiction, that there was no evidence to back the "public interest rationale" for the separation of commercial and investment banking. Except for deposit insurance (and even here, there were mutterings about moral hazard), the limits imposed on banking by the Glass-Steagall Act of 1933 were roundly condemned through the entire cadre of academic and corporate economists, as the old law was unceremoniously junked 66 years later. A few of us did worry about the loss of information that could result as the veil of bank secrecy was extended over additional transactions, but we were not really respectable. Today, we few, still not a happy few, stand on the high ground of observed recent experience and watch the survivors of the still acclaimed wave of financial innovation struggle defensively, if not repentantly, up the slopes of what Alan Greenspan called "shocked disbelief."

Ten years after its repeal, Glass-Steagall has a constituency again. Lord Turner, in his report to the Financial Services Authority (FSA), summed up the moral argument: "We have to prevent large commercial banks from taking the benefit of retail deposit insurance, lender of last resort access, and too big to fail status, and using these advantages in risky proprietary trading activities of little social value.”1 Mervyn King, Governor of the Bank of England, has called for firm separation of the "public utility" banks from the merchant banks. Paul Volcker has publicly complained that nobody in the White House or the Treasury Department has listened to his counsel that, if you wish to avoid more fiascos like those we have witnessed in the last year, you'd better take control of what insured depositories can do with the money. Giving the finger to Sandy Weill, with whom he had built the monstrous and dysfunctional Citicorp, John Reed then contributed a laconic statement of support for Volcker's position on the letters page of the New

\footnotetext{
${ }^{1}$ Griffiths, Katherine. "FSA’s last weapon in the new financial world will be discretion.” Telegraph, March 19, 2009. Hhttp://www.telegraph.co.uk/finance/newsbysector/banksandfinance/5012735/FSAs-last-weapon-in-the-new-financial-world-wil l-be-discrection.html H.
} 
York Times. ${ }^{2}$ The September/October 2009 issue of Harvard Magazine offers an article by David A. Moss, professor at that university's business school, with the flat statement: "The simple truth is that New Deal financial regulation worked. In fact, it worked remarkably well." ${ }^{3}$ I am going to dissent from that comment, too, because the net effect of the New Deal reforms in a time of rapid technological change was to diminish the franchise value of the banking license, from which much evil flowed. Then perhaps we can look ahead.

We start with the fact that the separation of commercial banking from investment banking, a shorthand term for the securities business, was not a new idea in 1933. It was the British custom and had been American law and custom until the turn of the twentieth century, when deposit-taking banks began forming "securities affiliates.” Such affiliates were first recognized in law by the McFadden Act of 1927. By 1929, they had taken over half the corporate underwriting business in the United States. The phenomenon was not entirely welcome. In 1930, an article in the first issue of Fortune worried that a commercial bank involved with the sale of securities might "get into promotional difficulties of which it should be judge rather than advocate." 4 Herbert Hoover in 1932 called for an end to "conditions which permit the credit machinery of the country to be made available without check for wholesale speculation in securities." 5 On the day after he succeeded Albert Wiggins as president of the Chase National Bank in 1933, Winthrop Aldrich announced his bank would cut its ties with its securities affiliate, proclaiming it "impossible to consider the events which took place during the past ten years without being forced to the conclusion that intimate connection between commercial banking and

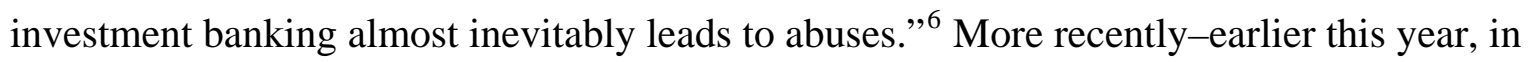

\footnotetext{
${ }^{2}$ Reed, John S. “Volcker’s Advice.” New York Times, October 21, 2009. Hhttp://www.nytimes.com/2009/10/23/opinion/l23volcker.html?_r=1\&scp=1\&sq=reed\%20volcker\&st=cse

${ }^{3}$ Moss, David A. “An Ounce of Prevention,” Harvard Magazine, Sept-Oct. 2009, 24.

${ }^{4}$ Fortune, February 1930, 138.

${ }^{5}$ Hoover, Herbert. “Statement on the Economic Recovery Program. May 17, 1932.

${ }^{6}$ Perkins, Edwin J. “The Divorce of Commercial and Investment Banking: A History,” The Banking and Law Journal, 88.6 (June 1971): 525.
} 
fact-Henry Kaufman agreed, arguing that "these problems are likely to be particularly acute in the context of a bank holding company with an incentive to cross-sell its products among its diverse customer base." 7

Abuse of securities powers by banks had not in fact played much of a role in the financial disasters of 1929-33. Most of the banks' worst violations were manipulating the stock market price of their own shares, and the activity that was most resented-the drainage of cash away from productive uses to the "call money" market that fed stock speculation-was done by the big corporations without the mediation of the banks in what we have recently and insistently been taught to call a shadow banking system. There has grown up a revisionist history that really there wasn't anything all that bad about the stock market of the late 1920s, led as it was by a combination of the partnership investment banks and the rapidly growing securities affiliates of the commercial banks.

In fact, there was a lot of misbehavior with other people's money in the 1920s. Looking back from his old age, George Moore, who would go on to create Citicorp from the chassis of First National City Bank, wrote that "People who did not live through it can scarcely imagine the Wall Street of the 1920s. It seemed that money was something you played with: everybody had it.” (Moore did not himself buy stocks: "If you work in the undertaker’s parlor," he wrote, "you're a little more careful how you cross the street.”) ${ }^{8}$ Some of the stories are quite like our current interests. Albert Wiggins in 1933, for example, was president and CEO of Chase, a member on 56 corporate boards of directors, and part of the executive committee of the Federal Reserve Bank of New York. His own board voted him a retirement salary of $\$ 100,000$ a year, and during his last four years with the bank he received total salary and bonuses of $\$ 1,500,000$. That's in 1933 dollars. "Wiggins," historian Donald Ritchie wrote in 1987 in a paper for the Senate Banking Committee, "protested that his associates from the bank had determined these generous

\footnotetext{
${ }^{7}$ Kaufman, Henry. The Road to Financial Reformation. NY: Wiley, 2009, 121.

${ }^{8}$ Moore, George S. The Banker's Life. NY: W. W. Norton \& Co., 1987, 70-71.
} 
emoluments. 'And I helped to fix theirs,' he added. . ..”9

There are three reasonable arguments that blame our recent financial disaster on the repeal of Glass-Steagall. The most obvious is that it invited bankers to venture out into water that was way over their heads. Martin Wolf, in the Financial Times, makes the obvious point, commenting that "Financial liberalisation and financial crisis go together like a horse and carriage.” ${ }^{10}$ George Moore, sent to represent National City Bank at the final conference between the House and Senate in 1933, said that the argument against deposit insurance was that the competence of bankers was not an insurable risk. Academics and mathematicians found it easy in recent years to peddle what were in reality very risky strategies because bankers had no notion of the dangers inherent in selling volatility.

Andrew Sheng in his new book From Asian to Global Financial Crisis makes the technical argument, presenting the modern financial system as a network subject to viral attack. “In network terms,” Sheng writes, “Glass-Steagall set up firewalls between networks to prevent contagion between them. Repeal of the act in 1999 set the stage for complete network integration and therefore massive contagion."11

The third argument is psychological and stresses the basic incompatibility of commercial banking and investment banking. The commercial banker looks at a loan and asks how the borrower is going to repay it, and, if he's any good, he expects a detailed answer; the investment banker looks at a financing and asks how he is going to sell the paper, and he will proceed happily with any plausible answer. In Sheng's more elegant formulation, “You cannot mix the culture of investment banking (where risk taking is key) and commercial banking (where prudence is vital) under one roof.” Within the bank, the proponent of originate-and-distribute enjoys a big advantage from day one in his competition on with the old-fashioned banker who wants to

${ }^{9}$ Modernization of the Glass-Steagall Act, Hearing Before the Committee on Banking, U.S. Senate. Washington, DC: GPO, July 30, 1987, 45.

${ }^{10}$ Wolf, Martin. “This time will never be different,” Financial Times, September 28, 2009, 8.

${ }^{11}$ Sheng, Andrew. From Asian to Global Crisis. NY: Cambridge University Press, 2009, 326. 
lend-and-hold: his profit comes at the start, off the top.

Twenty years ago, I wrote an article about Darla Moore of Chemical Bank, who with the lawyer Harvey Miller re-invented Debtor-in-Possession financing. She was about to marry the billionaire Richard Rainwater and saw no reason not to give her views about how the bank was run. Her description of how large loan applications were considered was, "You send it to Jimmy Lee. If he says he can blow it out the door, you make the loan; if he says he can't sell it, you don't make the loan.” Mr. Lee now performs these same functions for JPMorgan Chase, which is the name we now give to Chemical Bank. One should note that when Lee started his activities, Glass-Steagall was still the law; the only difference Gramm-Leach-Bliley made was that the new law expanded his list of potential customers. Joe Grundfest, when he was an U.S. Securities and Exchange Commission (SEC) Commissioner, liked to say that a term loan is nothing but an illiquid junk bond. This is not true, because the two instruments are on different ends of the great continuum that leads from relationship to transaction-but one can (and one did) behave as though it were true.

Government-supported securitization as a way to multiply the funds banks can lend goes back to the Federal Housing Administration in 1934, offering to insure twenty-year self-amortizing mortgages so Walter Bimson of Valley National Bank in Phoenix could sell them to insurance companies in the northeast and replenish his lendable funds. But those were real sales to third parties. Not until Bill Seidman's Federal Deposit Insurance Corporation (FDIC) invented the collateralized debt obligation (CDO), looking to resolve the savings and loan (S\&L) mess by selling with partial government guarantees the entire asset portfolios of failed depositories, did it become acceptable procedure to form structured investment vehicles (SIVs) that, with support from the sponsoring bank, could pretend to transfer the ownership of defective assets. Part of the rationale for Glass-Steagall had been to prevent such concealment.

Perhaps the closest link between the repeal of Glass-Steagall and the recent disaster is that they share a tap-root: the belief within the industry, in academia and especially among the government supervisors, banking (defined as lending money and getting it back) is no longer a profitable business. The job of pricing loans can be done more cheaply, if perhaps not so well, in 
securities markets.. But the banks are too important for the government to let them be chopped up by Schumpeterian creative destruction. Banks are special, as E. Gerald Corrigan, now of Goldman Sachs, insisted when he was president of the Federal Reserve Bank of Minneapolis; their deposit liabilities are the transaction balances of the economy. When a securities house goes bankrupt, its shareholders and creditors absorb the loss. There is no court-supervised bankruptcy procedure for banks despite the obvious need for some system to permit limiting the protection of careless lenders to a failing bank. The losses of a decapitalized banking system, as Andrew Sheng pointed out a dozen years ago in his study for the World Bank, ${ }^{12}$ are an implicit fiscal deficit, whether or not the institutions involved are formally declared too big to fail. It is worth remembering that the phrase "too big to fail" goes back to testimony in 1984 before the House Banking Committee by Todd Conover (an accountant, not a banker), defending his decision as Comptroller of the Currency that Continental-Illinois, then the tenth largest bank in the United States, could not be permitted to collapse, even if that meant that the FDIC had to borrow money from the Federal Reserve to pay off the purchasers of the holding company's commercial paper, some of which had been issued in the Caribbean as a tax dodge. Bernanke and Paulson and Geithner did not invent the expenditure of money ultra vires for pious purposes.

The effort of this paper is to get people to think a little more in new directions, so I am going to be discursive. There is certainly a case to be made that who regulates is more important than the laws themselves. Bill Martin, who really believed his job was to take away the punch bowl just when the party was getting interesting, would not have had Alan Greenspan's problem in deciding whether or not there was a bubble in housing. (Bill Martin, after his retirement from the Fed, warned his successor Arthur Burns that the quality of the nation's savings had been dropping. Burns said that the numbers looked okay, and Martin said, "People aren't saving any more so they can send their kids to college. They don't think they can do that now. They're saving to buy a piece of land in Virginia. That's a very different kind of savings.”13) I am prepared to argue

\footnotetext{
12 Sheng, Andrew, Ed.. Bank Restructuring: Lessons From the 1980s. Washington, DC: The World Bank, 1996.

${ }^{13}$ Mayer, Martin. The Fate of the Dollar. NY: Times Books, 1980, 334.
} 
that, if Chris Cox had been chairman of the SEC and Ben Bernanke chairman of the Fed in 1992, we would have rescued Drexel Burnham-and if Richard Breeden had been chairman of the SEC in spring 2008, Bear Stearns would have been dissolved. The Fed has always refused to accept that it regulates the banking system. The approved word has always been "supervised." What was not understood in Maiden Lane and still isn't is that when you supervise you become complicit.

The Glass-Steagall Act was intended to keep banks out of activities that might threaten the stability of the payments system or the financial markets. Farmers and merchants all over the country resented the call money market in New York that drained cash from their local banks, because speculative use of the money in the national money market was more profitable than conventional lending. A debt deflation nobody understood very well had placed immense burdens on enterprise, and there had been just enough skullduggery in the management of the large banks to give Congress a rationale for control. This was still the age of prohibition, before the great war taught government that the easy way to get something from an economy or a society was to pay a little extra for it.

So deposit-taking banks were forbidden to pay interest on demand deposits and were limited in the rates they could offer for time deposits, which could not be called savings accounts. They were prohibited from owning non-bank businesses, from offering their services interstate and from providing insurance or underwriting securities issuance, except for municipal paper. Private ownership of monetary gold was forbidden, and Federal Reserve banknotes were to become the national currency, except for dollar bills, which remained Treasury paper surrogates for silver ("payable in silver to the bearer on demand”) for another generation. Checks written on member banks of the Federal Reserve System had to be accepted for face value by other member banks of the System. The Federal Reserve was empowered to limit the use of margin in securities trading, and did.

Most important of all, to prevent runs on the banks, consumer deposits up to a maximum of \$2500 per account were insured by a new Federal Deposit Insurance Corporation that had a call on the Treasury if necessary. (The $\$ 2500$ number was chosen because that was then the largest 
permissible size for a postal savings account. ${ }^{14}$ ) Member banks had to keep a fraction of their money on deposit at the Federal Reserve Bank where they were a member, and this fractional reserve system was the engine of monetary policy, providing a multiplier for the actions of the open market committee. If the Fed added a thousand dollars to bank reserves by purchasing paper in the market or making a loan at the discount window, the result with a $10 \%$ reserve would be an increase of $\$ 10,000$ in the assets and liabilities of the banks. If the Fed sold a thousand dollars of paper into the market, pocketing the proceeds, banks would be compelled to cut their collective balance sheets by $\$ 10,000$. The banks had to square their accounts at the Fed every Wednesday afternoon.

Ralph Leach of J.P. Morgan used that bank's correspondent relationships around the country to create a market in "Fed Funds" that served the purposes once served by the call money market. Walter Wriston and John Exter then found a way to fund the money center banks through the issuance of negotiable CDs-and in 1969 the Fed, terrified by the collapse of the market for Chrysler paper following the bankruptcy of Penn Central, agreed to eliminate interest rate ceilings on bank liabilities expressed as negotiable CDs of more than $\$ 100,000$. Fear that a nascent Eurodollar market could create dollars offshore if foreign central banks got in the habit of making Eurodollar loans abroad led Fed chairman Arthur Burns to negotiate a deal with his European fellows that they would ship their excess dollar receipts to New York to be invested by the Fed in U.S. government securities "held for foreign official account.” Recurrent bouts of inflation gave a weird cast to the Fed's limits on the interest banks could pay on time deposits, as the Federal Reserve Board sat in solemn conclave to determine how large a television set a bank could give in return for a five-year certificate of deposit at below-market interest rates. A New England savings bank offered a Negotiable Order of Withdrawal, a "Now Account" that was in effect an interest-bearing checking account, and the facade of interest rate controls gradually fell off the system. Indeed, the Fed refused to interfere when Charles Keating's Lincoln Savings and Loan paid more than four percentage points of commission to what was then called Prudential-Bache to

\footnotetext{
${ }^{14}$ The Golembe Report, 25th Anniversary Ed., Washington, DC, 1992, 118.
} 
broker in deposits that would pay their customers two and three percentage points more than other S\&Ls were paying.

Then, quite suddenly-and this is still the age of Glass-Steagall-the Fed abdicated its control of the money supply, permitting Banc One to pass on through the banks' clearing systems the checks issued by Merrill Lynch for its Cash Management Account. There soon followed the home equity loan, sponsored by the banks, enabling American households to monetize the equity in their homes. I wrote the first article about the Cash Management Account, for Fortune, in 1981, and I asked Paul Volcker why he had permitted it, and he said, "It was one of those things where you look at it and think, 'That's interesting, I wonder where it will go,' and the next time you look at it it's so big you don't dare do anything about it.”

On the asset side of the ledger, the steps away from Glass-Steagall were more tentative. Senator Carter Glass regretted the separation of deposit banking and investment banking almost from the beginning, and history chipped away at the other controls. The law permitted banks to underwrite municipal bonds; in the 1960s, Comptroller James Saxon extended this power to revenue bonds. In 1956 and again in 1970, Congress enacted laws that expanded the asset powers of "bank holding companies," to be supervised by the Fed, which took a somewhat restricted view of what these holding companies should be permitted to do. For example, though the traditional banker gives the traditional borrower quite a lot of advice, the Fed prohibited bank holding companies from owning or operating management consulting firms. One of the “Article 20” powers the Fed granted the holding company was the right to form special purpose vehicles (SPVs) that would purchase the banks' loans and take them off the bank's balance sheet, the sort of thing that got the securities affiliates in such trouble in 1933. This happened on Volcker's watch and over his dead body-the vote was one of very few where the chairman dissented. Years later, in 2007, the majority that overruled him turned out to be right (for ill, not for good) in one significant aspect-the bank couldn’t escape ultimate responsibility for the SPVs and SIVs its holding company underwrote. But by the time that became clear, it was the taxpayer who was on the hook (Bamber and Spencer 2008, El-Erian 2008, Wessel 2009, Zandi 2009). Like the blind Indian savants confronted with an elephant, each of these sees a different reason why the banks 
diverted their own blood to transfuse the purchasers of the paper they had originated and distributed.

If we could make the world afresh, we would re-regulate banking by control over the instruments that insured depositories were permitted to trade and to hold as investments. Thirty years have passed since Scott Pardee, then the chief foreign exchange trader at the Federal Reserve Bank of New York, first proposed the creation of a financial Food and Drug Administration empowered to prevent the marketing or use of instruments with the potential to destabilize our financial systems. Scott lived in a world where periodically, as he put it, everybody ran to the same side of the boat. The damage was to some extent controlled because foreign exchange contracts, like wheat or oil futures contracts, involved deliverables. Elizabeth Warren at Harvard made a similar suggestion about a year ago, urging a vetting process especially for the trading instruments that can be created ad lib. Jan Kregel has pointed out that our markets are now organized to price the risk of future events rather than to value future income flows, which makes them much less useful in the allocation of resources. ${ }^{15}$

Change in the current disastrous markets isn't going to happen this time around. The industry has squared the Congress, and the Treasury, having played along with the game for lo these many years, is not well situated to throw any weight behind Secretary Geithner's correct instinct that we can never have financial stability until the derivatives trade is forced out of the over-the-counter nexus and into mandatory standardization and exchange trading.. I note in passing that I first said this in a book published in 1997. The most strongly argued objections to Geithner's original proposal are in fact the strongest arguments for it. Lufthansa complained that exchange-traded oil futures require players to post margin, and thus eat liquidity, but from the point of view of the taxpayers who have to supply the liquidity when the players in the OTC markets get it wrong, the exchanges stand sentinel-as the regulators so frighteningly don't-over the public's money.

\footnotetext{
${ }^{15}$ Kregel, Jan. “Managing the Impact of Volatility in International Capital Markets in an Uncertain World” Levy Institute of Bard College, Summary, 2009, 16-17.
} 
One of the instruments that should simply be banned is the CDO that jumbles together various loans, notes, receivables, mortgages, etc. The CDO is a fixed-income mutual fund with adverse selection in its construction. What may be gained in diversification is lost in incomprehensibility. The real-life origin of this instrument was Bill Seidman's desire to sell off the portfolios of the busted S\&Ls as "whole banks" rather than have his Resolution Trust Corp. break out the assets in conventional categories so they could be valued and sold to an informed market where the participants had the time, talent and resources to do due diligence. The questions the buy side might reasonably wish to have answered could be buried under the rubric of the rating. We have very bad experience in the art world in the selling of paintings where the expert is paid by the dealer. For two generations, the art historians who authenticated or failed to authenticate an alleged old master were paid a fixed percentage of the sales price, with the result that our museums are burdened with many paintings not really by the advertised artist. Not to put too fine a point on the matter, the CDO was developed as a way to conceal value, or the lack of it. Which meant that you couldn't sell it without guarantees, some way to swap assets in and out of the package, leading us through the swamp of the total return swap to the tar sands of the Credit Derivative Swap and the tar baby of the enormous taxpayer gift to Goldman Sachs in the rescue of AIG.

We could, in fact, keep banks from playing the CDO game. The big shillelagh in the closet is the power to award or deny-or adjust the premium on-deposit insurance. Even in today’s lets-be-kind-to-the-banks regulatory atmosphere, insured depositories obviously should be banned from investing in or trading a CDO-squared, or options with all-or-nothing triggers, or the lower tranches of collateralized mortgage obligations. The purpose, as Lord Turner wrote in his FSA report, is to "make the banking system an economic shock absorber, not itself a source of shocks.”

If the regulators are too timid to use their control of deposit insurance as a weapon, the derivatives problem can be dealt with by a revision of the bankruptcy law that ends the preference now given to such instruments by the securities legislation of 1999 and the bankruptcy legislation of 2005. There is no good reason in law or economics-no explanation other than pure political 
clout-why bilateral over-the-counter derivatives contracts, which are simply bets on the direction of prices, should be settled before the rest of a bankrupt estate and the claims on it. Exchange-traded contracts, of course, would continue to clear and settle as they do today.

Too big to fail is of course the worst problem. We have been forced to accept the idea that giant failed banks are not only entitled to blank checks from the government but may use those checks to expand. Banking is now a seriously overconcentrated industry. And there is no societal or economic benefit from the elephantiasis of banking. There are no economies of scale in banking once the bank’s deposits are greater than, say, \$5 billion, and the economies of scope claimed by the industry are in reality the profits that can be made by exploiting conflicts of interest. The work that should be done now by the economists and regulators would look to the separability of the parts of the holding company. For many years, the Fed insisted as part of its approval process in granting new powers to bank holding companies that the activities for which permission was requested would be "a source of strength" to the bank. The Congress could, I think, breathe life into such a requirement, keeping the capital of the "utility" side of the bank save from depredation by the “casino” bank. By denying the other subs access to the holding company’s capital unless the safety of the bank is beyond question, traders across the market and geographic spectrum could be compelled to pay close attention to the quality of their counterparties What we really want is an internalized private-sector Glass-Steagall.

What lies ahead of us right now is more serious than these arcana of banking powers and supervision. Quite inadvertently, the Federal Reserve has created a new and original banking system, destroying the fractional reserve control procedures with which we all grew up and substituting what is at the margin, though nobody at the Fed seems to recognize it, a $100 \%$ reserve plan, a throwback to Henry Simons and Irving Fisher and Lauchlin Currie. "Quantitative easing” leaves the community of banks with what are now again called “excess reserves,” after a generation when there were no excess reserves, if only because everything left over after a bank had met its reserve requirement was called "Fed Funds" and had market value. And as part of this process the Fed showed a profit from the seigniorage, which was paid to the Treasury and reduced the federal deficit. 
Other than jawboning and pious declarations about preventing inflation, monetary policy is pretty close to out the window in the new dispensation. Previously, with a 10\% reserve requirement and a loaned up system where the books had to be squared every other Wednesday, the Fed could pull, say, $\$ 100$ million out and know that the banks as a group would have to cut back on their loans by $\$ 900$ million dollars. Conversely, a stimulating Fed could be confident that the injection of $\$ 100$ million of what Milton Friedman called "high-powered money" would produce a billion dollars of new banking assets (loans and reserves).

Now it's one for one at best-and that only on the heroic assumption that a banking system unwilling to lend money from its existing pile of excess reserves will allocate new excess reserves to loans when the Fed seeks to stimulate, and when the purpose is stringency will cut back on lending rather than reduce its stash of excess reserves. We are assured by those Fed governors who give speeches that the Fed will be able to control what happens to the excess reserves because Congress now permits the Fed to pay interest on them, and for the same interest rates banks would rather keep their money at the Fed than lend it out. The New York Fed talks about taking money out through third-party repo; even if that works, it doesn't restore the multiplier.

Lord Turner has suggested that regulation of banks and securities houses should look to economic substance, not legal forms. If the economic function of the instrument is insurance, banks should be kept off the playing field. If the trading activity involves the pledging of liability structures that include insured deposits, the bank should be barred access to the trading room. (And meanwhile we need a little more understanding by regulators, academics, commentators and politicians that the banks as a group do not lose money by making wild bets on long shots; they lose by huge bets on what their algorithms and computers tell them are sure things. There are no sure things.) In all trading activities conducted over-the-counter, banks should be held to high know-your-customer standards, with inviolable rules for the posting of collateral and the maintenance of records that permit each participant in the market to know continuously the full degree of its exposure to every counterparty across the full range of markets.

I have been trying to find a cheerful thought to leave with you. About the best I can do is note that one of the worst worries of my generation can now be abandoned. When information 
technology was still new, law professor Harry Kalven noted his fear that through the agency of the computer, mankind would lose its benign capacity to forget. We know now that despite the violence of the shock, both the big banks and the cadre of bank regulators and supervisors-and academics-are shaking off the awful memories of 2008 and are setting up the same pins in the same alleys for the same players to try again. We will have to do this at least once more before we even try to get it right. 


\section{References}

Bamber, Bill and Andrew Spencer (2008). Bear Trap: The Fall of Bear Stearns and the Panic of 2008. NY: Brick Tower Press.

El-Erian, Mohamed (2008). $\quad$ When Markets Collide. NY: McGraw-Hill, 2008.

Fortune, February 1930

Griffiths, Katherine. “FSA's last weapon in the new financial world will be discretion.” Telegraph, March 19,

2009. http://www.telegraph.co.uk/finance/newsbysector/banksandfinance/5012735/FSAs-lastweapon-in-the-new-financial-world-will-be-discrection.html

Hoover, Herbert. "Statement on the Economic Recovery Program. May 17, 1932.

Kaufman, Henry (2009). The Road to Financial Reformation. NY: Wiley.

Kregel, Jan (2009). "Managing the Impact of Volatility in International Capital Markets in an Uncertain World.” Levy Institute of Bard College Summary. Fall.

Mayer, Martin (1980). The Fate of the Dollar. NY: Times Books.

Modernization of the Glass-Steagall Act (1987). Hearing Before the Committee on Banking, U.S. Senate. Washington, DC: GPO.

Moore, George S. (1987). The Banker’s Life. NY: W. W. Norton \& Co.

Moss, David A. (2009). “An Ounce of Prevention.” Harvard Magazine, September/October.

Perkins, Edwin J. (1971). “The Divorce of Commercial and Investment Banking: A History.” The Banking and Law Journal 88.6 (June): 438-528.

Reed, John S. (2009). “Volcker’s Advice.” New York Times, October 21. http://www.nytimes.com/2009/10/23/opinion/123volcker.html? r=1\&scp=1\&sq=reed\%20vol cker\&st $=$ cse

Sheng, Andrew, Ed. (1996). Bank Restructuring: Lessons from the 1980s. Washington, DC: The World Bank.

Sheng, Andrew (2009). From Asian to Global Crisis. NY: Cambridge University Press.

The Golembe Report, 25 ${ }^{\text {th }}$ Anniversary Ed. (10992). Washington, DC. 
Turner, Lord, Adair (2009). The Turner Review: A Regulatory Response to the Global Banking Crisis. London: Financial Services Authority. March.

Wessel, David (2009). In Fed We Trust. NY: Crown Business.

Wolf, Martin (2009). “This Time Will Never Be Different.” Financial Times, September 28.

Zandi, Mark. Financial Shock. Upper Saddle River, NJ: FT Press. 